\title{
Application and development of pyrolysis technology in petroleum oily sludge treatment
}

\author{
Ziyi Wang ${ }^{1}$, Zhiqiang Gong ${ }^{+\dagger}$, Zhenbo Wang ${ }^{\dagger}$, Xiaoyu $\mathrm{Li}^{2}$, Zhiwei Chu ${ }^{1}$ \\ ${ }^{1}$ State Key Laboratory of Heavy Oil, China University of Petroleum (East China), 266580, Qingdao, China \\ ${ }^{2}$ College of Mechanical and Electronic Engineering, Shandong University of Science and Technology, 266580, Qingdao, China
}

\begin{abstract}
With the enhancement of public awareness of environmental protection, the harm of oily sludge has gradually been paid attention to. As a kind of dangerous solid waste, the arbitrary disposal of oily sludge will cause quite serious harm to both the environment and human beings. Research on the treatment methods of oily sludge has become a hot spot recently. At present, treatment methods of oily sludge are various, mainly including pyrolysis, direct combustion, freeze-thaw treatment, biological treatment, solvent extraction, thermochemical cleaning, ultrasound-assisted treatment or joint technology, etc. Based on the consideration of economic benefits, social benefits and treatment difficulties, pyrolysis has been considered to be the most appropriate method for oily sludge treatment. Syngas, liquid oil and char can be obtained from pyrolysis of oily sludge, which can meet different needs. In this paper, the pyrolysis technology of oily sludge is reported in detail, including pyrolysis methods, operational parameters and pyrolysis products of oily sludge. On the basis, the advantages and limitations of oily sludge pyrolysis technology are discussed, together with the report of feasibility of pyrolysis technology of oily sludge. Moreover, the development trend of pyrolysis technology of oily sludge is prospected for the future work.
\end{abstract}

Keywords: Activated carbon, Oily sludge, Product distribution, Pyrolysis technology

\section{Introduction}

In the process of oil extraction and refining, a large amount of oily sludge is produced every year, which has become an obstacle to the development of petrochemical industry. It has been an urgent problem to treat oily sludge properly [1]. However, current treatment technology for common solid waste cannot treat oily sludge both economically and effectively. As a result, the accumulation of oily sludge increases continually. It is estimated that the cumulative amount of oily sludge in the world exceeds 1 billion tons. About 60 million tons of oily sludge are accumulated every year in petroleum industry in the world. Moreover, the annual output is still showing a growing trend. With the rapid development of society, the public's awareness of environmental protection has gradually increased. The harm of oily sludge has been recognized [2]. Many countries and regions have made strict regulations for oily sludge, which promotes the development of treatment technology for oily sludge [3].

Many treatment methods of oily sludge have been developed in recent years, such as pyrolysis, direct combustion, freeze-thaw treatment, biological treatment, solvent extraction, thermochemical cleaning, ultrasound-assisted treatment and joint technology [4-7]. However, there are always drawbacks more or less for these technologies. For example, the biological treatment technology calls for large floor area and long processing period, limiting the processing capacity. In addition, the possibility of secondary pollution is also a great problem, hindering the large-scale application of this technology [8-10]. Combustion is widely used for oily sludge treatment. The main advantages of combustion include small floor area and fast processing speed. However, toxic and harmful gases will be released into the atmosphere during the treatment process [11-14]. It is not only necessary to realize the harmless treatment of oily sludge, but also to recycle resources as much as possible in response to the call of energy saving and emission reduction [15].

So far, much work has been carried out to confirm the feasibility of the pyrolysis of oily sludge. The advantages of pyrolysis technology of oily sludge are outstanding including the fast processing speed, the strong pollution control, small area covering, and fewer requirements for the properties of oily sludge. Although the technology
This is an Open Access article distributed under the terms of the Creative Commons Attribution Non-Commercial License (http://creativecommons.org/licenses/by-nc/3.0/) which permits unrestricted non-commercial use, distribution, and reproduction in any medium, provided the original work is properly cited.

Copyright (C) 2021 Korean Society of Environmental Engineers
Received November 23, 2019 Accepted February 12, 2020

${ }^{\dagger}$ Corresponding author

Email: gongzhiqiang@upc.edu.cn,dxl437@sina.com

Tel: +86 +0532 86983480

ORCID: 0000-0002-3055-961X 
has been popularized and applied broadly, there is still large room for the improvement of pyrolysis. Pyrolysis products include syngas, pyrolysis oil and char, which can be recycled and used in various industries. Pyrolysis of oily sludge can not only reduce the amount of sludge, but also recover the energy and reduce the pressure caused by the exhaustion of petrochemical energy [16-20]. The improvement of pyrolysis effect can be considered from two aspects. On the one hand, try to increase the recovery rate of oil and syngas while reducing energy consumption in the treatment process [21]; on the other hand, improve the benefit of pyrolysis products create more economic benefits to make up for the cost in the treatment process. Researchers use oily sludge as raw material to manufacture high value-added products such as activated carbon or carbon nanotubes, and the products showed excellent performance [22].

Besides, pollutants in oily sludge can be effectively controlled with pyrolysis. It is found that the treatment of oily sludge by thermal solution can also effectively fix the heavy metals contained in char, reducing the impact of heavy metal to the environment [23].

Although many researchers have made research on the pyrolysis technology of oily sludge, in recent years, there are few reviews specifically targeted on pyrolysis technology of oily sludge in petrochemical industry. In this paper, the characteristics of oily sludge in petrochemical industry have been described detailed. The application and progress of oily sludge pyrolysis in recent years are summarized and discussed. It is believed that this paper will provide valuable information for future research on oily sludge treatment.

\section{Material and Methods}

\subsection{Main Sources of Oily Sludge}

Oily sludge appears in every production stage of petrochemical industry. In particular, the output of several kinds of oily sludge account for the most. For example, landing sludge produced during exploitation, concentrated sedimentation tanks sludge, bottom of storage tank sludge produced during tank cleaning and oily sludge produced during chemical refining process [24-26].

The properties and composition of oily sludge change in a large range with the joint factors like sampling time, place and many other factors. Even for the same kind of oily sludge, its properties will fluctuate in a large range. For example, in the report of da Silva et al., water content is between $30-90 \%$, oil content is between $5-60 \%$ and the sediments vary between $4-7 \%$ in oily sludge [27] and similar phenomenon has been reported for many times [28]. For different kinds of oily sludge, this situation is more obvious. The content and characteristics of oil phase substances in oily sludge is also a very important index. The oil phase in oily sludge is mainly composed of alkanes, aromatic hydrocarbons, bitumen and resins. For example, in the report of Lin et al. [29], the proportion of each composition is usually composed of 40-52\% alkanes, $28-31 \%$ aromatic hydrocarbons, 8-10\% bitumen and 7-22.4\% resins, approximately. These substances lack biodegradability and can have a lasting impact on the soil around the storage area. When recycling energy materials, the composition of the oil phase will have a great impact on the recovery difficulty. Table 1 summarized the basic proportion and physical properties of several kinds of oily sludge.

Ultimate analysis and proximate analysis are often used. The $\mathrm{C}$ and $\mathrm{H}$ content of oily sludge is extremely high. In the research of Chen et al. [24], The C in oily sludge accounted for $83.36 \%$, and the $\mathrm{H}$ content reached $11.87 \%$. The content of $\mathrm{O}, \mathrm{N}$ and $\mathrm{S}$ did not exceed 3\%. In the study of Huang et al. [30], The $\mathrm{C}$ content of the three oily sludges remained between $50-65 \%$, and the $\mathrm{H}$ content remained at around $10 \%$. The content of $\mathrm{N}$ did not exceed $1 \%$, while the content of $\mathrm{S}$ varies greatly, with the lowest being $1.7 \%$ and the highest reaching $5.1 \%$. In the study of $\mathrm{Hu}$ et al., The $\mathrm{C}$ content of oily sludge reached $60 \%$, the $\mathrm{H}$ content was $17.6 \%$, and the $\mathrm{N}$ content was very low, only $0.05 \%$ [31]. Data shows that oily sludge is rich in $\mathrm{C}$ and $\mathrm{H}$, which shows a very high recovery value. The content of $\mathrm{N}$ is relatively low, generally not more than $1 \%$, while the content of $\mathrm{S}$ has a greater correlation with the quality

Table 1. Composition Difference and Evaluation of Typical Oily Sludge

\begin{tabular}{|c|c|c|c|}
\hline Source & Feature & Evaluation & Reference \\
\hline Landing sludge & $\begin{array}{l}\text { - Rich in asphaltene, silt, gum, additives and heavy metals } \\
\text { - High content of water (more than 10\%) } \\
\text { - High content of } \mathrm{N} \text { and } \mathrm{P} \\
\text { - Low content of } \mathrm{H} \text { and } \mathrm{C} \\
\text { - Brown or black appearance }\end{array}$ & $\begin{array}{l}\text { - Larger viscosity } \\
\text { - Low calorific value. } \\
\text { - High risk factor }\end{array}$ & {$[120,121]$} \\
\hline $\begin{array}{l}\text { Tank bottom } \\
\text { sludge }\end{array}$ & $\begin{array}{l}\text { - Rich in hydrocarbons, asphaltenes, paraffin, water and } \\
\text { inorganic solids, such as sand, iron sulfide and iron oxide } \\
\text { - High content of C (up to 80\%) and H (up to 10\%) } \\
\text { - High content of metals }\end{array}$ & $\begin{array}{l}\text { - High calorific value and recovery value } \\
\text { - Easy for secondary pollution } \\
\text { - Less contact with residents }\end{array}$ & {$[24,122,123]$} \\
\hline Refining sludge & $\begin{array}{l}\text { - Rich in benzene series, phenols and additives } \\
\text { - High content of bacteria and water }\end{array}$ & $\begin{array}{l}\text { - With an irritating odor } \\
\text { - Complex properties and high viscosity } \\
\text { - Low recovery value } \\
\text { - Centralized and easy to collect }\end{array}$ & {$[124,125]$} \\
\hline $\begin{array}{l}\text { Pond sediment } \\
\text { sludge }\end{array}$ & $\begin{array}{l}\text { - High moisture content and low hydrocarbon content } \\
\text { - High content of } \mathrm{N} \text { and } \mathrm{S} \text {. }\end{array}$ & $\begin{array}{l}\text { - High yield } \\
\text { - Serious leak } \\
\text { - High risk of secondary pollution } \\
\text { - Low recovery value }\end{array}$ & {$[25,55]$} \\
\hline
\end{tabular}


of the crude oil, and generally does not exceed 5\% [13].

Before pyrolysis treatment, oily sludge is generally dried. Ash content in oily sludge tends to be high, staying between $40-60 \%$. The volatile content generally occupies a higher proportion, which is second only to ash in dry sludge. A large amount of data shows that the volatile content in oily sludge is extremely high, which can generally reach $30-50 \%$ in dry sludge. The content of fixed carbon is relatively low, generally less than 5\% [32, 33].

\subsection{Harmfulness of Oily Sludge}

Oily sludge usually contains abundant pathogens, heavy metals, which could cause great harm to the surrounding environment [34]. The pathogens can be removed by pyrolysis, but heavy metals are still distributed in pyrolysis products. Sulfur and nitrogen compounds might change and migrate in pyrolysis process, discharging into the atmosphere with syngas and distributing in the pyrolysis oil or char, which is not conducive to the application of the products. Harmful substances influence the determination of treatment methods and conditions a lot and need to be focused.

\subsubsection{Heavy metal}

It is very important to understand and control the migration and transformation of heavy metals. According to a large number of reports, oily sludge usually contains many metals mainly including Na, K, Ca, Li, Ca, Ba, Cu, Zn, Cr, Ni, Pb, V [4, 35-38]. Alkali metals exist in nearly all the oily sludge, while the content of heavy metals varies greatly which lack biodegradability and will cause long-term pollution of soil. The change of content and species not only relate to the quality of the crude oil, but also to the origin, type and treatment process. For example, the tank bottom sludge, which are taken from the cleaning process, usually contains a large quantity of heavy metals. $\mathrm{Cu}$ and $\mathrm{Zn}$ seem to be most abundant, and the concentration can reach 1\% [12, 39, 40].

Heavy metals are generally very harmful. For example, hexavalent chromium can invade animals through digestive tract, respiratory tract, skin and mucous membrane, and accumulate in liver, kidney and endocrine gland [41-43]. Lead is difficult to be eliminated once it enters the human body. It can directly damage human brain cells, especially the fetal nervous system, and can cause congenital mental retardation [44]. The toxicity of vanadium is relatively low, but the compounds of vanadium have high toxicity to human and animals. The toxic effect is related to the valence state, solubility and the way of uptake of vanadium. The higher the valence state is, the greater the toxicity is [45]

Heavy metals can be classified into three categories according to their biodegradability: a) heavy metal components that is soluble in water or easily to leach; b) heavy metals that cannot dissolve directly in water, but can be reduced or oxidized under acidic conditions or in the presence of strong oxidants. c) heavy metals that are extremely insoluble in water and unable to be oxidized or reduced [39]. As is known, the main purpose of oily sludge treatment is to realize the recycling of oily sludge, and the safety of products is very important, too. It is necessary to understand the toxic and harmful substances as the migration and transformation is of great importance.

Usually, the existence form of heavy metal compounds is not stable, especially in high temperature environment. Wang et al.
[46] studied the migration and transformation of heavy metals during sludge pyrolysis, including $\mathrm{Cu}, \mathrm{Zn}, \mathrm{Cr}, \mathrm{Ni}, \mathrm{Pb}$, and $\mathrm{Cd}$. By comparing with MEP of China and GB 32486-2009, it was found that the contents of $\mathrm{Cu}, \mathrm{Zn}$ and $\mathrm{Cr}$ in the samples were much higher than normal, which meant that both the oily sludge and the char could not be directly applied to agricultural production or urban greening. At the same time, the contents of $\mathrm{Ni}, \mathrm{Pb}$ and $\mathrm{Cd}$ are lower, and the content of $\mathrm{Zn}$ is slightly higher than the standard of acid soil. The most important is that pyrolysis technology can fix heavy metal ions in char very well. In report of Gong et al, migration of heavy metal in high temperature environment was studied. When the temperature was high, $\mathrm{Cr}, \mathrm{Cu}$ and $\mathrm{Pb}$ volatilized in gaseous form, while $\mathrm{Zn}$ and $\mathrm{Ni}$ in solid phase were still fixed in residual [47].

Heavy metals which are quite toxic to organisms can be gradually enriched in the biological chain [48]. The bioaccumulation method has excellent effect on the treatment of heavy metals [49]. However, the soil and water around the storage area of oily sludge will be infringed, which is no longer suitable for the survival of animals and plants [48]. Thus, the balance and development of the ecological environment will be seriously damaged. Eventually, toxicity of heavy metals will act on human beings through the food chain and they are usually not biodegradable [50, 51]. Numerous studies have demonstrated the toxicity of a single type of heavy metal to organisms and the effects of a variety of heavy metals on soil microorganisms and bacterial communities. In order to explain impact of heavy metals in oily sludge on environment and biology, many researchers used microbial population as experimental objects to explain the harmfulness [52]. All the results showed that a large number of heavy metals have considerable toxic effects on organisms and seriously endangered the ecosystem, indirectly proving the harm of oily sludge [53].

In order to reduce the harm caused by heavy metals, a variety of methods has been tried, such as phytoremediation. However, the harm caused by heavy metals cannot be ignored. Heavy metals in oily sludge should be closely monitored. However, there are few studies on the migration and transformation of heavy metals during pyrolysis process.

\subsubsection{Formation and release of nitrogen/sulfur compounds}

It has been found that there are many sulfur and nitrogen compounds in oily sludge. These compounds undergo transformation and migration during pyrolysis, and eventually distributing in pyrolysis products, which will reduce the quality of the products. Especially when the sulfur content in pyrolysis oil is high, the quality of pyrolysis oil will be poor.

Generally, the proportion of nitrogen in oily sludge is high. By analyzing the original sample of oily sludge and the pyrolysis products, the evolution of nitrogen compounds in oily sludge were determined [54]. It is pointed out that the forms of nitrogen in the pyrolysis products include amine- $\mathrm{N}$, imine- $\mathrm{N}$, pyridine- $\mathrm{N}$, and pyrrole-N. The proportion of sulfur compounds in oily sludge is also relatively high, and it is one of the points that need to be focused on, too. For example, gaseous sulfur compounds generally have peculiar odor, which has a great impact on the atmosphere. Sulfur compounds in industrial production process can lead to catalyst poisoning, which is not conducive to production. Some sulfur compounds can also lead to reactor corrosion [55]. Moreover, 
it is one of the main reasons for acid rain formation [56]. Sulfur compounds could gradually enrich in the process of transportation and storage, and the content in heavy oil can reach 6-8\% eventually.

Similar to nitrogen, organic and inorganic sulfur compounds will transform and migrate during pyrolysis. Inorganic sulfur compounds exist in the solid particles mainly as sulfate, while organic sulfur mainly existed in the oil phase in the forms of aliphatic and heterocyclic sulfurs. $\mathrm{H}_{2} \mathrm{~S}$ is the main gas pollutant produced during the pyrolysis of oily sludge, which comes from the decomposition of thiol and sulfide. When the pyrolysis temperature is high, the sulfate in the solid residue decompose, and more sulfur will distribute in gaseous and oil phase products, which leads to the reduction of the quality of pyrolysis oil. Higher temperatures allow organic sulfur converts into inorganic sulfur, producing large quantities of metal sulphides and further fixing them in solid residues [56]. In the early study, it was found that nitrogen and hydrogen were easily desorbed at pyrolysis temperatures between $473-773^{\circ} \mathrm{C}$, while the sulfur in char was only slightly desorbed. At the same time, higher pyrolysis temperature leads to an increase of benzene, toluene, ethylbenzene and xylene content in syngas [57].

As high-risk solid waste, oily sludge contains other harmful substances such as polycyclic aromatic hydrocarbons (PAHs) and PHCs [4, 48, 58-61], mainly including chrysene, pyrene, anthracene and fluorine [62]. PAHs is highly toxic with strong carcinogenicity, which can cause human cancer through breathing or direct skin contact. So far, biological treatment is regarded as the most effective methods [63, 64].

Such a large amount of oily sludge has become a heavy burden for the rapid development of the petrochemical industry. If these wastes could not be treated properly, serious impact could be brought to the environment [27]. The determination of harmful substances in oily sludge and the strict monitoring of the transformation and migration of these harmful substances are the basis of thorough treatment of oily sludge. Therefore, it will still be important in the future work. Before treatment, it is necessary to have clear understanding on the basic composition of oily sludge, including oil/water/sediment content, and oil phase composition etc. Appropriate subsequent processing steps can only be determined by detailed understanding the characteristics of oily sludge [28].

\section{Development of Pyrolysis Technology}

As an effective and reasonable treatment method for oily sludge, pyrolysis has been greatly developed in recent years. Many researchers have improved the pyrolysis technology and made great progress. In this paper, the development of pyrolysis in recent years and the development are summarized and evaluated for future work.

\subsection{Overview of Pyrolysis of Oily Sludge}

The pyrolysis technology of oily sludge refers to the conversion of macromolecular organics in oily sludge into gas or liquid products with smaller molecules by heating in the anaerobic environment to realize the recovery and utilization of energy. In order to meet different needs, many new technologies have been applied to the pyrolysis of oily sludge. At present, the main improvements of this technology can be classified as follows:

1) Control the operation conditions precisely. This is mainly reflected in the use of thermogravimetric analysis instrument, GC-MS technology to strictly monitor the pyrolysis process and products, to provide a reference for the large-scale application of this technology.

2) Reduce the treatment input by improving the heating method. Improve processing speed and effect can reduce the operation cost, shorten the treatment time and increase the treatment capacity.

3) Add catalyst to the oily sludge. Various catalysts are helpful to shorten the reaction time, reduce the reaction activation energy of the product, improve the energy utilization efficiency and reduce the production input. On the other hand, by controlling the quality and proportion of certain product, it can facilitate the recovery and utilization of the product and improve the benefit.

4) Add co-thermal materials. Recovery rate of pyrolysis oil or syngas can be greatly improved. The shortcomings of high $\mathrm{O}$ content, low $\mathrm{H}$ content and high acidity of pyrolysis oil in individual pyrolysis can be made up. This advantage is conducive to the application of the technology in large-scale production.

5) Strengthen the control of harmful substances. Controlling toxic and harmful substances, minimizing the harm of oily sludge and various products to the environment is the ultimate goal of the process.

In addition to technological innovation, some pretreatment methods have also been used in order to get better pyrolysis effect. For example, dehydration and grinding can effectively improve the pyrolysis speed and enhance the heat transfer efficiency, so that the pyrolysis process can be carried out more smoothly.

\subsection{Technical Advantages of Oily Sludge Pyrolysis}

Among the current technologies for oily sludge treatment, pyrolysis technology has considerable advantages.

Biochemical treatment is one of the currently widely used treatment technologies. Thorough processing effect is the main advantage of this technology. However, the biological treatment cycle is longer. Treatment cycle often takes several days or more. Moreover, the survival conditions of the strains are relatively harsh, and the requirements for conditions such as $\mathrm{pH}$ and temperature are more stringent, which leads to the limitation of biological treatment of oily sludge under extreme conditions [65, 66]. In comparison, the pyrolysis method has lower requirements on the external environment and can be operated in most conditions.

Combustion is another typical process method. The combustion method can be applied to the treatment of most solid wastes, but it is not ideal in the treatment process of oily sludge. It is difficult to realize the recovery of energy substances in oily sludge. The thermal energy generated during the combustion process cannot be stored, which is not conducive to energy recovery and utilization. At the same time, a large amount of heavy metal particles, dioxins and fly ash are generated, causing environmental pollution.

Extraction is a common method for resource recovery [67]. The process of extracting oily sludge is simple and fast, but most of the currently used extractant is relatively expensive, and there 
is a certain loss during operation, which increases the cost of treatment. Supercritical fluid extraction technology is still being explored and developed. The physical properties of the method are relatively small, phase equilibrium and transfer research are insufficient. High equipment cost, complicated operation and non-continuous operation have become the main obstacles hindering the development of this method. On the other hand, oil recovered directly cannot be used directly, and further refining is still needed, which increases the processing cost and cycle [68, 69].

Freeze-thaw technology is only suitable for certain types of oily sludge. For areas without natural low temperature conditions, the advantages of freeze-thaw technology are not obvious. So far, domestic and foreign studies on the treatment of oily sludge by the freeze-thaw method are very limited. More attention is paid to the mechanism and theoretical demonstration [70]. In terms of energy recovery, pyrolysis can make up for the shortcomings of combustion [71]. The disadvantages of the pyrolysis method are high equipment requirements, high processing costs and maintenance costs.

\subsection{Classification of Pyrolysis Technology}

This paper classifies and evaluates the pyrolysis technologies currently used from several perspectives, which are listed in Table 2.

\subsection{Pretreatment}

In order to facilitate the treatment of oily sludge, some pretreatment methods are needed. For example, oily sludge contains a lot of water. Nevertheless, water will not participate in the main reaction, resulting in the waste of energy and the decline of processing capacity. In order to improve the treatment efficiency and enhance the heat transfer efficiency, it is necessary to take some pretreatment measures.

\subsubsection{Dehydration}

The resources of oily sludge determine its high moisture content. Dehydration is one of the most common pretreatment methods, through which the volume of oily sludge can be reduced as soon as possible. After a long time of accumulation and storage, water is easy to carry harmful substances in oily sludge to the atmosphere or infiltrate into the surrounding soil, causing serious secondary pollution. Dehydration can also significantly reduce possibility of secondary pollution in transportation, storage and treatment process. It has been mentioned that the moisture contained in oily sludge is difficult to be recycled because the oil and water form a stable state of $\mathrm{O} / \mathrm{W}$ or $\mathrm{W} / \mathrm{O}$. During pyrolysis, when the temperature exceeds the boiling point of water, the free water and the combined water will evaporate in the form of gas, causing rapid dissipation of energy. Especially in slow pyrolysis, it is difficult to retain water to the pyrolysis stage of petroleum hydrocarbon. Therefore, for most experiments, water has little effect on pyrolysis results. High water content will also lead to uneven sampling, resulting in deviation of analysis results. In order to make the results of pyrolysis experiments representative, pre-dehydration of the raw materials was often used as a pretreatment method before pyrolysis [31, 72].

It is common to use oven to dry the moisture in the oily sludge, and the temperature is usually set at $105^{\circ} \mathrm{C}[24,73]$. If the temperature is too high, light hydrocarbon will be evaporated easily, resulting in environmental pollution and energy waste. When there are many volatile substances in oily sludge, it is more suitable to separate

Table 2. Classification and Evaluation of Pyrolysis Technology

\begin{tabular}{|c|c|c|c|c|}
\hline \multicolumn{2}{|c|}{ Classification } & \multirow{2}{*}{$\begin{array}{l}\text { Advantage } \\
\text { - High yield of liquid oil } \\
\text { - High processing efficiency }\end{array}$} & \multirow{2}{*}{$\begin{array}{l}\text { Shortcoming } \\
\text { - Lower internal temperature } \\
\text { - Incomplete pyrolysis reaction }\end{array}$} & \multirow{2}{*}{$\begin{array}{l}\text { Reference } \\
{[126-128]}\end{array}$} \\
\hline Heating & Fast pyrolysis & & & \\
\hline rate & $\begin{array}{l}\text { Slow } \\
\text { pyrolysis }\end{array}$ & $\begin{array}{l}\text { - Thorough pyrolysis reaction } \\
\text { - High yield of syngas }\end{array}$ & $\begin{array}{l}\text { - Limited processing power } \\
\text { - High energy input }\end{array}$ & [129] \\
\hline \multirow[b]{2}{*}{ Reactor } & $\begin{array}{l}\text { Fixed bed } \\
\text { pyrolysis }\end{array}$ & $\begin{array}{l}\text { - Wide application range and strong adaptability } \\
\text { - Low equipment maintenance costs } \\
\text { - Precise control and strong maneuverability }\end{array}$ & $\begin{array}{l}\text { - Poor and uneven heat transfer } \\
\text { - Not conducive to catalyst replacement and } \\
\text { regeneration }\end{array}$ & {$[106,130]$} \\
\hline & $\begin{array}{l}\text { Fluidized } \\
\text { bed pyrolysis }\end{array}$ & $\begin{array}{l}\text { - High heat and mass transfer efficiency } \\
\text { - Uniform heating } \\
\text { - Stable operation }\end{array}$ & $\begin{array}{l}\text { - Severe back mixing } \\
\text { - Poor gas-solid contact } \\
\text { - Serious collision of catalyst particles } \\
\text { - Heavy wear on pipes and equipment }\end{array}$ & {$[131,132]$} \\
\hline \multirow{2}{*}{$\begin{array}{l}\text { Heat } \\
\text { mode }\end{array}$} & $\begin{array}{l}\text { Thermal } \\
\text { radiation }\end{array}$ & $\begin{array}{l}\text { - Stable operation } \\
\text { - Low cost } \\
\text { - Wide application range }\end{array}$ & $\begin{array}{l}\text { - Poor heating rate } \\
\text { - Uneven heating } \\
\text { - Poor Processing capacity }\end{array}$ & {$[29,56]$} \\
\hline & $\begin{array}{l}\text { Microwave } \\
\text { heating }\end{array}$ & $\begin{array}{l}\text { - High heat transfer efficiency } \\
\text { - Large processing capacity }\end{array}$ & $\begin{array}{l}\text { - Additional receptor required } \\
\text { - High equipment operating and maintenance } \\
\text { costs } \\
\text { - Complicated operation }\end{array}$ & {$[75,133-138]$} \\
\hline Other & $\begin{array}{l}\text { Vacuum } \\
\text { pyrolysis }\end{array}$ & $\begin{array}{l}\text { - No protective gas needed } \\
\text { - Good air tightness and high heating efficiency } \\
\text { - Thorough pyrolysis reaction } \\
\text { - High organic conversion }\end{array}$ & $\begin{array}{l}\text { - High equipment cost } \\
\text { - Difficult to operate } \\
\text { - High equipment operating and maintenance } \\
\text { costs }\end{array}$ & {$[81,139]$} \\
\hline
\end{tabular}


the water from the oil by vacuum distillation of the rotating evaporator after extraction because some hydrocarbons, especially volatile fractions, will be lost during the drying process [74, 75].

\subsubsection{Grind and mix}

The dried oily sludge is usually grinded before pyrolysis for better heat transfer [31, 56, 72]. Tripath et al. [76] found that sample with oversized particle size could reduce the heat transfer efficiency from the surface to the core, resulting in incomplete pyrolysis of the sample and a poor pyrolysis performance. In many reports, oily sludge has undergone grinding before pyrolysis, and the size of particles is generally below $2-5 \mathrm{~mm}$ [72, 77, 78].

Biomass and catalyst are the common materials to mix with oily sludge to improve the effect. For biomass, it needs to be crushed and then mixed with oily sludge after drying [79]. For catalysts, some researchers activated or modified the additives in advance to improve the pyrolysis effect. In order to make the additives distribute more evenly in oily sludge, researchers often dissolve the additives with water first, and then mix them with oily sludge [80].

\subsection{Pyrolysis Technology of Oily Sludge}

In view of the good effect of pyrolysis technology, it has been greatly developed in recent years. Although the pyrolysis technology of oily sludge shows excellent performance, effectively reducing the volume of oily sludge and controlling toxic and harmful gases, the technology still needs to be further improved. There are many disadvantages, such as low recovery efficiency, high treatment cost and low quality of pyrolysis products. Research on co-pyrolysis of biomass and the addition of catalyst are particularly prominent in recent years. After years of exploration and development, there have been many researchers studying the pyrolysis of oily sludge. In this paper, various pyrolysis methods in recent years has been summarized and briefly evaluated.

\subsubsection{Pyrolysis of oily sludge}

With the help of new heating technology and analysis means, the pyrolysis effect of oily sludge is continuously improved. The reaction process and mechanism are gradually clear. It is the key point to find the most suitable pyrolysis conditions for the most effective treatment. In the pyrolysis process, the main pyrolysis parameters include temperature, heating rate, treatment capacity carrier, gas flux and feed rate. Although researchers have studied over several decades on oily sludge, the pyrolysis performance is still unstable.

Temperature is one of the most important operating parameters in the complex pyrolysis process, which has great influence on the pyrolysis products, especially the yield and quality [81]. In the primary stage of temperature rise, olefin, alkanes, long-chain fatty acids and esters, aliphatic nitrile and amide will volatilize in gaseous form. As the temperature increases, aliphatic and thermally unstable organic oxygen tend to be cracked into gaseous products. Organic nitrogen gradually forms aromatic species, especially the positive heterocyclic type. Numerous results indicated that with the increase of temperature, the solid residue decreased and the gas phase composition increased. In order to get more oil products rather than gas products in some processes, it is necessary to control the temperature within the proper temperature range. High temperature can accelerate the reaction rate and the decomposition of organic matter, but more small molecules tends to be produced. For different pyrolysis materials, the choice of pyrolysis temperature is different. Table 3 lists some choices of for different materials. In the processing of different raw materials, the optimum temperature is often slightly different. Finding the optimal temperature can not only reduce energy consumption, but also achieve optimal utilization of product.

For biomass, conversion temperature is generally lower than $500^{\circ} \mathrm{C}$. As the temperature increases, the yield of syngas gradually increases. For sewage sludge, the pyrolysis temperature is generally below $600^{\circ} \mathrm{C}$, and that of oily sludge is similar to sewage sludge, which distributes between $500^{\circ} \mathrm{C}$ and $700^{\circ} \mathrm{C}$. In some reports, with the addition of catalysts or biomass as co-heating materials, the proper pyrolysis temperature decreased. It can be roughly determined that the proper pyrolysis temperature of oily sludge is in the range of $400-700^{\circ} \mathrm{C}$. Due to the difference of components in oily sludge, the pyrolysis temperature of oily sludge still needs to be determined again before experiments.

With the increase of pyrolysis temperature, the content of small hydrocarbons in gas phase and the yield of pyrolysis oil increases gradually. In pyrolysis reaction, ring structure of benzene homologues is difficult to break the, but some straight chain is not the same, such as $\mathrm{C}-\mathrm{C}$ and $\mathrm{C}-\mathrm{H}$ of aliphatic compounds, which is easy to break at high temperature [82]. In particular, the presence of hydroxyl, methyl, methylene and other groups in long-chain hydrocarbon substances will also break with the increase of temperature, promoting the generation and release of syngas.

Heating rate also has a great influence on the pyrolysis

Table 3. Selection of Pyrolysis Temperature

\begin{tabular}{lccc}
\hline Processing Target & Pyrolysis Temperature & Main Product & Ref. \\
\hline Olive mill solid waste & $350^{\circ} \mathrm{C}$ and $450^{\circ} \mathrm{C}$ & biochar & sludge-char \\
Sewage Sludge & $450^{\circ} \mathrm{C}$ & sludge-char and bio-oil & {$[140]$} \\
Palm Oil Sludge & $550^{\circ} \mathrm{C}$ & bio-oil and biochar products & {$[142]$} \\
Paper Mill Sludge & $1000 \mathrm{~K} / \mathrm{s}, \quad 500^{\circ} \mathrm{C}$ & oil product and syngas & {$[143]$} \\
Oily Sludge and Rice Husk & $600^{\circ} \mathrm{C}$ & bio-oil & bio-oil \\
Sewage Sludge and Lignocellulosic & $300^{\circ} \mathrm{C}$ & saturates-enriched light oil \\
Sewage Sludge & $500^{\circ} \mathrm{C}$ to $800^{\circ} \mathrm{C}$ & bio-oil & {$[144]$} \\
Oily Sludge & $500^{\circ} \mathrm{C}$ & {$[13]$} \\
Japanese Larch & $450^{\circ} \mathrm{C}$ & {$[146]$} \\
\hline
\end{tabular}


performance. With the development of heating technology, heating rate has been improved. New heating methods have been introduced into pyrolysis of oily sludge technology, accompanied by the improvement of pyrolysis effect. Kan et al. [83] indicated that when the heating rate increasing from $10^{\circ} \mathrm{C} / \mathrm{min}$ to $100^{\circ} \mathrm{C} / \mathrm{min}$ in the pyrolysis process, the mass loss gradually shifts to the high temperature segment, especially in the main reaction segment of the pyrolysis process. The slow pyrolysis mainly produces solid and gas products. In contrast, in the fast pyrolysis process, the yield of pyrolysis oil can reach the maximum, which can be up to nearly 90\% under ideal conditions [82, 84].

As carrier gas, nitrogen and argon are widely used. Inert gas is important but does not participate in the reaction. The types of protective gases do not have much effect on the pyrolysis process, but the flux determines the residence time of products, especially gaseous products, indirectly affecting the pyrolysis process. In the study of Lin et al., the reaction time was determined by the flux of nitrogen flow [21]. Lilly Shen et al. pointed out that nitrogen flow speed should be at least 5 times faster than the vulcanization speed [85]. In many studies, nitrogen flux is generally distributed between $50-200 \mathrm{~mL} / \mathrm{min}$ in related reports [80, 86-89]. It is worth mentioning that the protective gas is required to enter the reactor before pyrolysis to ensure that air is not mixed in pyrolysis atmosphere.

After years of research, pyrolysis technology of oily sludge has become more and more mature. It is necessary to deepen the understanding of the reaction mechanism and process, which is the way to control the reaction process and improve pyrolysis effect [90, 91]. In the future research work, the study of research on kinetics of oily sludge pyrolysis will still be a focus. On this basis, the pyrolysis of oily sludge with catalysts and the co-pyrolysis of oily sludge with biomass could be analyzed, too. Moreover, the scale of production can be enlarged on the basis.

\subsubsection{Co-pyrolysis technology}

Biomass is ideal raw materials as alternative of fossil fuel for the wide range of sources and high production. Some researchers have found that the addition of biomass materials has a positive effect on the pyrolysis of oily sludge. However, bio-oil is still unable to meet the need for production or to be directly applied to the devices currently in use. For bio-oil produced from biomass alone, the ratio of $\mathrm{H} / \mathrm{C}$ is too low and the ratio of $\mathrm{O} / \mathrm{C}$ is too high [92]. High acidity, low calorific value, high oxygen content (which can be up to $35-60 \%$ ) and high viscosity are ubiquitous characteristics of bio-oil [93-96]. Many researchers mixed biomass with oily sludge to improve the ratio of $\mathrm{H} / \mathrm{C}$ as pyrolysis raw materials because the ratio of $\mathrm{H} / \mathrm{C}$ of oily sludge is usually high. These shortcomings have been improved by co-pyrolysis of oily sludge and biomass. The morphology and structure of char will change, as the content of light hydrocarbon in syngas increases. Lin et al. [29] mixed oily sludge with rice husk for pyrolysis to investigate the interaction between biomass and oily sludge. The experiment results showed that the quality of the pyrolysis oil has been improved. The content of heavy sextant and oxygenated compounds reduced while the content of saturated hydrocarbon, chain hydrocarbon and aromatic hydrocarbon increased. Because of the secondary reaction, the yields of $\mathrm{H}_{2}$, $\mathrm{CO}$ and short-chain hydrocarbons increased. In addition to biomass, materials such as rubber, tire and plastics also have potential to be used for co-thermal reaction to improve the quality of pyrolysis products [97-100].

\subsubsection{Addition of pyrolysis catalyst}

With the development of research, adding catalyst to improve the reaction efficiency has become a common method [101]. Considering environmental protection and economy, cheap and nontoxic catalyst is the first choice. Many of them have shown positive effects, but it is difficult to determine the optimum one.

The main purpose for adding catalyst includes the following points:

1) Increase the yield of pyrolysis gas and pyrolysis oil, especially the yield of light hydrocarbon.

2) Improve the quality of pyrolysis oil like reducing the distribution of $\mathrm{S}$ and $\mathrm{N}$ in the oil phase.

3) Control the formation and discharge of pollutants, especially gas products such as ammonia and hydrogen sulfide.

These catalysts mainly include sodium-based catalysts, potassium based catalysts, calcium-based catalysts, aluminum-based catalysts, iron-base catalysts, etc. Table 4 lists classification and evaluations of certain catalysts.

The initial purpose of adding catalyst is to improve pyrolysis efficiency, so that higher yield of pyrolysis oil and syngas can be got in a shorter time and at lower temperature. In order to explore the effect of catalysts on the pyrolysis of oily sludge and select the most suitable catalysts, Shie et al. carried out a series of studies, which provided a pretty systematic reference for research work. Aluminum compounds $\left(\mathrm{Al}, \mathrm{Al}_{2} \mathrm{O}_{3}\right.$, and $\left.\mathrm{AlCl}_{3}\right)$, iron compounds $\left(\mathrm{Fe}, \mathrm{Fe}_{2} \mathrm{O}_{3}, \mathrm{FeSO}_{4} \cdot 7 \mathrm{H}_{2} \mathrm{O}, \mathrm{FeCl}_{3}\right.$, and $\left.\mathrm{Fe}_{2}\left(\mathrm{SO}_{4}\right)_{3} \cdot \mathrm{nH}_{2} \mathrm{O}\right)$ and some other inexpensive catalysts were studied [102]. They also studied the effect of sodium and potassium compounds, including (1) sodium compounds ( $\mathrm{NaOH}, \mathrm{NaCl}$ and $\left.\mathrm{Na}_{2} \mathrm{CO}_{3}\right)$, and (2) potassium compounds ( $\mathrm{KCl}, \mathrm{KOH}$ and $\mathrm{K}_{2} \mathrm{CO}_{3}$ ) [103]. In addition to metal compounds as catalysts, the fly ash, sludge ash, waste zeolite and polyvinyl alcohol (PVA) were also used as additives on improving the pyrolysis performance of oily sludge [104]. In subsequent studies, other types of catalysts were gradually used in the pyrolysis process, including FCC, $\mathrm{Cu}\left(\mathrm{NO}_{3}\right)_{2} \cdot 3 \mathrm{H}_{2} \mathrm{O}$ [105], and they also showed positive effect. Alkaline earth metal catalysts showed positive impact on the pyrolysis reaction, which can promote the progress of the reaction and the conversion of organic matter. The addition of $\mathrm{KOH}$ can significantly improve the quality of pyrolysis oil, and the addition of $\mathrm{KCl}$ and $\mathrm{Na}_{2} \mathrm{CO}_{3}$ has the best performance in improving the yield of pyrolysis oil. The addition of aluminum-based catalysts has a positive effect on the increase of oil yield, and the optimal reaction temperature is reduced. As a non-toxic catalyst, aluminum-based catalysts show good catalytic effects.

Under high temperature environments, Iron-based catalysts show better catalytic performance than aluminum-based catalysts. The addition of $\mathrm{Fe}$ has a significant effect on the improvement of gas product yield, and the effect of $\mathrm{Fe}_{2}\left(\mathrm{SO}_{4}\right)_{3} \cdot \mathrm{nH}_{2} \mathrm{O}$ on the conversion efficiency of organic matter is the most obvious. Calcium-based catalyst is also a common non-toxic cheap catalyst. $\mathrm{CaO}$ has the ability to promote the decomposition of hydrocarbons and can promote ammonia production. $\mathrm{CaO}$ has the ability to promote the decomposition of hydrocarbons and can promote ammonia 
Table 4. Commonly Used Types of Catalysts and Their Range of Use

\begin{tabular}{|c|c|c|}
\hline Catalyst type & & Ref. \\
\hline \multirow{6}{*}{ Alkali metal compound } & $\mathrm{NaOH}$ & \\
\hline & $\mathrm{NaCl}$ & \\
\hline & $\mathrm{Na}_{2} \mathrm{CO}_{3}$ & {$[75,80,129]$} \\
\hline & $K C l$ & {$[15,80,129]$} \\
\hline & $\mathrm{KOH}$ & \\
\hline & $\mathrm{K}_{2} \mathrm{CO}_{3}$ & \\
\hline \multirow{3}{*}{$\begin{array}{l}\text { Aluminum and } \\
\backslash \text { Aluminum compound }\end{array}$} & $A l$ & \multirow{3}{*}{ [102] } \\
\hline & $\mathrm{Al}_{2} \mathrm{O}_{3}$ & \\
\hline & $\mathrm{AlCl}_{3}$ & \\
\hline \multirow{5}{*}{ Ferro-based additives } & $\mathrm{Fe}$ & \multirow{5}{*}[80,102,119,147]{} \\
\hline & $\mathrm{Fe}_{2} \mathrm{O}_{3}$ & \\
\hline & $\mathrm{FeSO}_{4} \cdot 7 \mathrm{H}_{2} \mathrm{O}$ & \\
\hline & $\mathrm{FeCl}_{3}$ & \\
\hline & $\mathrm{Fe}_{2}\left(\mathrm{SO}_{4}\right)_{3} \cdot \mathrm{nH}_{2} \mathrm{O}$ & \\
\hline \multirow{2}{*}{ calcium-based catalyst } & $\mathrm{CaO} / \mathrm{Ca}(\mathrm{OH})_{2}$ & {$[33,148]$} \\
\hline & $\mathrm{CaCO}_{3}$ & [149] \\
\hline \multirow{2}{*}{ Nickel-based catalyst } & $\mathrm{Ni}(\mathrm{OH})_{2}$ & {$[150]$} \\
\hline & $\mathrm{Ni}_{2} \mathrm{O}_{3}$ & [149] \\
\hline $\mathrm{TiO}_{2}$ & & [149] \\
\hline $\mathrm{MgCl}_{2} \cdot 6 \mathrm{H}_{2} \mathrm{O}$ & & \multirow{2}{*}{ [147] } \\
\hline $\mathrm{CoCl}_{2} \cdot 6 \mathrm{H}_{2} \mathrm{O}$ & & \\
\hline \multicolumn{3}{|l|}{$\mathrm{NiCl}_{2} \cdot 6 \mathrm{H}_{2} \mathrm{O}$} \\
\hline Ash & & {$[80,90,151-153]$} \\
\hline
\end{tabular}

production. $\mathrm{CaCO}_{3}$ can be used as a substitute for $\mathrm{CaO}$ in high temperature environment. In syngas, the content of $\mathrm{CO}_{2}$ and $\mathrm{CO}$ increased and the content of $\mathrm{H}_{2}$ decreased after adding $\mathrm{CaCO}_{3}$. Ash is readily available and inexpensive. It is a good idea to use ash as a catalyst. In the past experiments, the addition of ash showed a good catalytic ability for the improvement of oil yield. With the quantity rising, the yield of syngas reduces. The addition of metal-based catalysts often has a certain positive impact on the pyrolysis process, but the process and mechanism are still unclear.

Suitable catalysts can greatly improve the pyrolysis effect and the quality of products. It is still the goal of future work to explore the specific mechanism of catalysts in sludge pyrolysis.

\section{Pyrolysis Products and Derivatives}

The pyrolysis products mainly present in three states, liquid oil, syngas and char. Oil and syngas are mostly used as fuel, but char could be recycled in many ways. The application of char needs further investigation because of the presence of harmful substances such as heavy metals. In this paper, the application of pyrolysis products has been evaluated and summarized.

\subsection{Yield Distribution of Pyrolysis Products}

Oil, gas, and char are the products of pyrolysis of oily sludge. During the pyrolysis process, controlling the yield and quality of products is an important goal. Among the three pyrolysis products, there is still much organic matter in char, yield of char will be higher than ash content. Considering the large amount of inorganic matter in oily sludge, the yield of char is generally high. During the pyrolysis process, most of the organics will be released as gaseous products. Oil, as a fuel with high calorific value and easy storage, is the most desired product to be recycled. Without catalysts and additives, only a small amount of oil will be obtained at high temperatures, generally less than $10 \%$ [106-108].

The product yield is affected by many factors, such as pyrolysis temperature, heating rate and other operating parameters, the characteristics of oily sludge and the presence of catalysts or co-heating materials all have an impact on the product distribution [55]. The properties of oily sludge have the greatest influence on the yield of each product, especially the oil content. Higher oil yields can be obtained under low temperature pyrolysis conditions, and high temperatures can help the decomposition of organic matter in oily sludge. The yield of pyrolysis gas will increase, and some oils will also decompose. Changing trends in productivity is a difficult task. In order to determine the optimal pyrolysis conditions, a large amount of basic work still needs to be invested. On the other hand, the pyrolysis product is not pure, and the change of the yield will be accompanied by the change of product composition. Therefore, it is not wise to pursue high yield of a specific product alone, and the composition needs to be closely monitored.

\subsection{Analysis on the Application of Char}

Many factors need to be considered in the application of char. At present, the application of char mainly includes the following ways:

1) Fuel. For char with high calorific value, it could be used as an alternative energy to alleviate the crisis caused by the shortage of fossil fuel.

2) Soil amendment. When the leaching rate of heavy metals is lower than the relevant standard and the calorific value of char is relatively low, the char could be used as soil amendment.

3) Building material. It is also an important way to solidify char as a building material.

4) Carbon materials. For char with high carbon content and abundant pore structure, it can be used as raw material for high value-added products such as electrode materials.

According to the characteristics of char, there are many ways to use it. Calorific value is an important index for the recovery and utilization of char [109]. When the calorific value of pyrolysis char reaches a certain level, it can be used as fuels like coal. In some studies, the calorific value of pyrolysis char is quite high, even higher than some traditional fuels. As reference, heating values of some conventional and unconventional solid, liquid and gaseous fuels are listed in Table 5 [110]. Some char has quite high calorific value compared to coal sold on the market. For example, in the study of Qin et al. [20], the maximum calorific value of char can reach $50.61 \mathrm{MJ} \cdot \mathrm{kg}^{-1}$, exceeding many traditional fuels. However, not all char has high calorific value [34].

Usually, oily sludge has high carbon content, which provides the possibility of preparing carbon materials with oily sludge as 
Table 5. Heating Values of Some Conventional and Unconventional Solid, Liquid and Gaseous Fuels

\begin{tabular}{lc}
\hline \multicolumn{1}{c}{ Fuels } & Heating value \\
\hline & $14,600-26,700 \mathrm{~kJ} \cdot \mathrm{kg}^{-1}$ \\
Plastics, wood, paper, rags, garbage & $17,600-20,000 \mathrm{~kJ} \cdot \mathrm{kg}^{-1}$ \\
Wood & $16,000-20,000 \mathrm{~kJ} \cdot \mathrm{kg}^{-1}$ \\
Dry sewage sludge & $12,000-20,000 \mathrm{~kJ} \cdot \mathrm{kg}^{-1}$ \\
Wet sewage sludge & $1,000-3,000 \mathrm{~kJ} \cdot \mathrm{kg}^{-1}$ \\
Gas-oil & $45,500 \mathrm{~kJ} \cdot \mathrm{kg}^{-1}$ \\
Black liquor & $12,500-15,500 \mathrm{~kJ} \cdot \mathrm{kg}^{-1}$ \\
Natural gas & $38,000 \mathrm{~kJ} \cdot \mathrm{kg}^{-1}$ \\
Char-oven gas & $19,000-22,000 \mathrm{~kJ} \cdot \mathrm{kg}^{-1}$ \\
Synthetic coal gas & $10,800 \mathrm{~kJ} \cdot \mathrm{kg}^{-1}$ \\
Blast-furnace gas & $4,400-5,300 \mathrm{~kJ} \cdot \mathrm{kg}^{-1}$ \\
\hline
\end{tabular}

raw material. For example, char can be made into activated carbon through further processing, which can be used in water treatment. For char with low metal leaching rate, it could be used as soil amendment [111].

At the same time, the formation of char is indispensable in the pyrolysis process of oily sludge. Therefore, how to process the char generated in the pyrolysis process into high value-added products is another goal of studies. After many attempts, it has been found that the production of activated carbon from char has a very good prospect. The quality of activated carbon processed from oily sludge is mainly reflected in the strength of adsorption capacity. Some reports showed the excellent properties of activated carbon, which lays a foundation for future development and study.

In the report of Zhou et al. [112], the adsorption capacity of activated carbon was tested. It was found that pyrolysis temperature not only had an effect on the yield of activated carbon, but also had an effect on the adsorption capacity of activated carbon [113]. Results showed that the activated carbon had mesoporous characteristics, the average aperture was $6.32 \mathrm{~nm}$, the aperture was 0.5098 $\mathrm{cm}^{3} \cdot \mathrm{g}^{-1}$ and the specific surface area was $631.8 \mathrm{~m}^{2} \cdot \mathrm{g}^{-1}$. The activated carbon also showed an excellent adsorption performance in the adsorption test. Meng et al. [114] used oily sludge as raw material to prepare nitrogen-doped porous carbon. After testing and verification, the nitrogen-doped porous carbon possessed favorable features for excellent $\mathrm{CO}_{2}$ adsorbent. $\mathrm{Li}$ et al. also used oily sludge as raw material to prepare porous carbon for super capacitors, and good results were obtained [115].

\subsection{Liquid Oil and Syngas}

Liquid oil and syngas are the main components of the pyrolysis products of oily sludge just like char. Recovery of liquid oil and syngas from oily sludge has raised much concern.

For the syngas, it is ideal if $\mathrm{H}_{2}$ and $\mathrm{CO}$ account for larger proportion. By comparing the pyrolysis effect of different oily sludge, it is found that the gas products have a great correlation with the nature of oily sludge and pyrolysis conditions. For example, in the presence of $\mathrm{O}$, the yield of $\mathrm{H}_{2}$ and $\mathrm{CO}$ in pyrolysis products will both decrease. The higher heating rate is also detrimental to the production of hydrogen [116]. Pyrolysis temperature has the greatest impact on the yield of oil and syngas. In the range of $350-530^{\circ} \mathrm{C}$, the main gas products include methane, ethane, ethyl- ene, propane and propylene. It is worth mentioning that the yield of light hydrocarbon increases with the increase of temperature, while the aromatic compounds decrease [74]. When the pyrolysis temperature raised from $400^{\circ} \mathrm{C}$ to $500^{\circ} \mathrm{C}$, the gas yield did not change significantly. As the pyrolysis temperature further increased, the gas yield increased sharply, reaching the maximum at $600^{\circ} \mathrm{C}$. The gases produced during pyrolysis mainly consist of $\mathrm{H}_{2}$, $\mathrm{CO}, \mathrm{CO}_{2}, \mathrm{CH}_{4}$ and some short-chain hydrocarbons. For liquid oil, the main components include alkanes, olefin, aromatic hydrocarbons, heavy oxygen hydrocarbons and substituted aromatic hydrocarbons [117, 118].

In the process of pyrolysis, harmful gases such as $\mathrm{H}_{2} \mathrm{~S}, \mathrm{HCN}$ and $\mathrm{SO}_{2}$ will be discharged together with light hydrocarbon substances and eventually exist in liquid oil and syngas. It is necessary to meet certain industry standards for applying the pyrolysis products of oily sludge to commerce. It is worth noting that the nitrogen and sulfur compounds are particularly harmful to machinery. Even in the subsequent treatment process, sulfur and nitrogen compounds would be discharged into the atmosphere and cause air pollution if they could not be properly treated. Experiments showed that the control of operating conditions and the addition of catalyst could play a very good role in reducing the generation and discharge of these pollution substances [119].

\subsection{Prospect of Future Research Work}

Feasibility of pyrolysis of oily sludge has been confirmed in a large number of studies, and the advantages of this technology are obvious. Nevertheless, the drawbacks of pyrolysis of oily sludge also exist. Therefore, in the future work, there is still much work to do to solve the existing problems.

As is known, economic efficiency is always one of the decisive factors. At present, the high cost of treatment technology is one of the main factors hindering the development and promotion of this technology. How to reduce operating costs while increase revenue is an important object for future work.

It is necessary to reduce the treatment cost and increase the value of the products. On one hand, the most suitable operating conditions should be determined to reduce unnecessary energy waste, at the same time, the yield of expected products could be promoted. On the other hand, through precise control of operating conditions, the quality of specific products can be increased to improve economic benefits. A large number of reports showed that the pyrolysis technology of oily sludge required precision equipment.

Environmental monitoring will be more stringent in the future, and the treatment of oily sludge will be more refined. Monitoring of heavy metals, nitrogen or sulfides compound distributed in products and PAHs in oily sludge will remain the focus of future work. Only a detailed understanding of the formation and migration of harmful substances can minimize their formation and emission.

The application of char will be a hot topic because char has a wide range of applications including agriculture, construction, decoration, and so on. However, due to the complex composition of oily sludge, which may also contain some harmful substances, many tests are needed before using the char.

Oily sludge is a huge burden for the development of petrochemical industry. At the same time, oily sludge is a misplaced resource, 
which can be reasonably recycled and a large amount of energy can be recovered. Treatment of oily sludge will still be an important task in the future. Moreover, vigorously developing the pyrolysis technology of oily sludge has a considerable reference value and guiding role for the treatment of hazardous solid waste.

\section{Conclusions}

Pyrolysis has been widely used to treat oily sludge and reduce the influence of toxic and harmful substances to environment. In this paper, the source and characteristics of oily sludge have been summarized and evaluated.

Oily sludge comes from a wide range of sources, including landing sludge, tank bottom sludge, refining sludge and pond sediment, accounting for the largest proportion. However, the properties of these kinds of sludge vary greatly, leading to difficulties in treatment and recovery. How to control the migration and transformation of various harmful substances in oily sludge is also one of the key factors to be considered, especially heavy metals, sulfur compounds, nitrogen compounds, PAHs and PHCs. Among them, heavy metals are the most harmful. Common metals include $\mathrm{Cr}, \mathrm{Pb}, \mathrm{V}$, $\mathrm{Zn}, \mathrm{Hg}$, etc. Heavy metals are difficult to degrade naturally, which will cause long-term effects on the environment. Comprehensive consideration, the pyrolysis technology has obvious advantages in the treatment of oily sludge. After pyrolysis, most of the metals will remain in the char. For syngas, a small amount of metals will be discharged in the form of gas, and a large number of $\mathrm{N}$ and S compounds will transform into atmosphere with foul odor. PAHs and PHCs could be recycled effectively.

In order to improve the pyrolysis effect and enhance the heat transfer efficiency, the new pyrolysis system has been applied. Adding biomass and catalysts has become two major directions of choice. A large number of results showed that adding biomass could improve the yield and quality of light components, while adding catalyst could shorten the reaction time, reduce the reaction temperature or control the generation and emission of hazardous substances, which plays a positive role in improving the reaction effect.

The pyrolysis technology of oily sludge is relatively mature after long-term development, which provides a guarantee for the large-scale promotion of this technology in the future.

\section{Acknowledgment}

The research was supported by State Key Laboratory of Pollution Control and Resource Reuse Foundation (NO. PCRRF19023), the Natural Science Foundation of Shandong Province (NO. ZR2017 BEE042), and the Fundamental Research Funds for the Central Universities of China (NO. 18CX02150A).

\section{Author Contributions}

Z.W. (Ph.D. student) wrote the manuscript. Z.G. (Ph.D.) conceived the study and led the project. Z.W. (Professor) reviewed and edited the manuscript. X.L. (Ph.D.) reviewed and edited the manuscript. Z.C. (M.D. student) collected and analyzed related literatures. All authors read and approved the manuscript.

\section{References}

1. Bagheri M, Roshandel R, Shayegan J. Optimal selection of an integrated produced water treatment system in the upstream of oil industry. Process Saf. Environ. Prot. 2018;117:67-81.

2. Taheri A, Taheri A, Fathivand AA, Mansouri N. Risk assessment of naturally occurring radioactive materials (NORM) in the hydrocarbon sludge extracted from the south pars gas field in Iran. Process Saf. Environ. Prot. 2019;125:102-120.

3. Hu G, Li J, Zeng G. Recent development in the treatment of oily sludge from petroleum industry: A review. J. Hazard. Mater. 2013;261:470-490.

4. Islam MN, Jung S-K, Jung H-Y, Park J-H. The feasibility of recovering oil from contaminated soil at petroleum oil spill site using a subcritical water extraction technology. Process Saf. Environ. Prot. 2017;111:52-59.

5. Mnif I, Sahnoun R, Ellouz-Chaabouni S, Ghribi D. Application of bacterial biosurfactants for enhanced removal and biodegradation of diesel oil in soil using a newly isolated consortium. Process Saf. Environ. Prot. 2017;109:72-81.

6. Kumar S, Mandal A, Guria C. Synthesis, characterization and performance studies of polysulfone and polysulfone/polymergrafted bentonite based ultrafiltration membranes for the efficient separation of oil field oily wastewater. Process Saf. Environ. Prot. 2016;102:214-228.

7. Zubaidy EAH, Abouelnasr DM. Fuel recovery from waste oily sludge using solvent extraction. Process Saf. Environ. Prot. 2010;88:318-326.

8. Ji L, Fu X, Wang M, et al. Enzyme cocktail containing NADH regeneration system for efficient bioremediation of oil sludge contamination. Chemosphere 2019;233:132-139.

9. Liu Y, Liu Y, Liu Z, Zhang A. Strengthening effects of ammonia nitrogen on the harmless biological treatment of oily sludge. Chem. Ecol. 2019;35:20-35.

10. Zare N, Bonakdarpour B, Amoozegar MA, et al. Using enriched water and soil-based indigenous halophilic consortia of an oilfield for the biological removal of organic pollutants in hypersaline produced water generated in the same oilfield. Process Saf. Environ. Prot. 2019;127:151-161.

11. Chen G-B, Li J-W; Lin H-T, Wu F-H, Chao Y-C. A Study of the Production and Combustion Characteristics of Pyrolytic Oil from Sewage Sludge Using the Taguchi Method. Energies 2018;11:2260.

12. Hu G, Li J, Hou H. A combination of solvent extraction and freeze thaw for oil recovery from petroleum refinery wastewater treatment pond sludge. J. Hazard. Mater. 2015;283:832-840.

13. Lin B, Huang Q, Mujahid A, Wang F, Chi Y, Yan J. Continuous catalytic pyrolysis of oily sludge using U-shape reactor for producing saturates-enriched light oil. P. Combust. Inst. 2019;37:3101-3108.

14. Jasmine J, Mukherji S. Impact of bioremediation strategies on slurry phase treatment of aged oily sludge from a refinery. 
J. Environ. Manage. 2019;246:625-635.

15. Lin J, Sun S, Ma R, et al. Characteristics and reaction mechanisms of sludge-derived bio-oil produced through microwave pyrolysis at different temperatures. Energ. Convers. Manage. 2018;160: 403-410.

16. Liu X, Yao T, Lai R, et al. Recovery of crude oil from oily sludge in an oilfield by sophorolipid. Pet. Sci. Technol. 2019;37:1582-1588.

17. Gong Z, Wang Z, Wang Z, Fang P, Meng F. Study on the migration characteristics of nitrogen and sulfur during co-combustion of oil sludge char and microalgae residue. Fuel 2019;238:1-9.

18. Gong Z, Wang Z, Wang Z, Fang P, Meng F. Study on pyrolysis characteristics of tank oil sludge and pyrolysis char combustion. Chem. Eng. Res. Des. 2018;135:30-36.

19. Chen Y, Zhang L, Zhang Y, Li A. Pressurized pyrolysis of sewage sludge: Process performance and products characterization. J. Anal. Appl. Pyrolysis. 2019;139:205-212.

20. Qin J, Jia Y, Li X, Liu Y, Lei Y, Gao J. Sludge char-to-fuel approaches based on the catalytic pyrolysis II: heat release. Environ. Sci. Pollut. Res. 2018;25:36581-36588.

21. Lin B, Wang J, Huang Q, Ali M, Chi Y. Aromatic recovery from distillate oil of oily sludge through catalytic pyrolysis over Zn modified HZSM-5 zeolites. J. Anal. Appl. Pyrolysis. 2017;128:291-303.

22. Cha JS, Park SH, Jung SC, et al. Production and utilization of biochar: A review. J. Ind. Eng. Chem. 2016;40:1-15.

23. He J, Strezov V, Kan T, et al. Effect of temperature on heavy metal(loid) deportment during pyrolysis of Avicennia marina biomass obtained from phytoremediation. Bioresour. Technol. 2019;278:214-222.

24. Chen L, Zhang XD, Sun LZ, Xie XP, Yang SX, Mei N. Study on the fast pyrolysis of oil sludge by PY-GC/MS. Pet. Sci. Technol. 2019;37:2108-2113.

25. Wu X-F, Qin H-B, Zheng Y-X, et al. A novel method for recovering oil from oily sludge via water-enhanced CO2 extraction. J. CO2. Util. 2019;33:513-520.

26. Egazar'yants SV, Vinokurov VA, Vutolkina AV, Talanova, MY, Frolov VI, Karakhanov EA. Oil Sludge Treatment Processes. Chem. Tech. Fuels Oils 2015;51:506-515.

27. da Silva LJ, Alves FC, de Franca FP. A review of the technological solutions for the treatment of oily sludges from petroleum refineries. Waste Manag. Res. 2012;30:1016-1030.

28. Ramirez D, Kowalczyk RM, Collins CD. Characterisation of oil sludges from different sources before treatment: High-field nuclear magnetic resonance (NMR) in the determination of oil and water content. J. Pet. Sci. Eng. 2019;174:729-737.

29. Lin B, Huang Q, Chi Y. Co-pyrolysis of oily sludge and rice husk for improving pyrolysis oil quality. Fuel Process. Technol. 2018;177:275-282.

30. Huang Q, Wang J, Qiu K, et al. Catalytic pyrolysis of petroleum sludge for production of hydrogen-enriched syngas. Int. J. Hydrog. Energ. 2015;40:16077-16085.

31. Hu G, Li J, Zhang X, Li Y. Investigation of waste biomass co-pyrolysis with petroleum sludge using a response surface methodology. J. Environ. Manage. 2017;192:234-242.

32. Gong Z, Du A, Wang Z, Fang P, Li X. Experimental Study on Pyrolysis Characteristics of Oil Sludge with a Tube Furnace
Reactor. Energ. Fuel. 2017;31:8102-8108.

33. Panek P, Kostura B, Cepelakova I, Koutnik I, Tomsej T. Pyrolysis of oil sludge with calcium-containing additive. J. Anal. Appl. Pyrolysis. 2014;108:274-283.

34. Barry D; Barbiero C; Briens C; Berruti F. Pyrolysis as an economical and ecological treatment option for municipal sewage sludge. Biomass Bioenerg. 2019;122:472-480.

35. Xiao W, Yao X, Zhang F. Recycling of Oily Sludge as a Roadbed Material Utilizing Phosphogypsum-Based Cementitious Materials. Adv. Civ. Eng. 2019;2019:1-10.

36. Nansa VM, Heydarinasab A, Otadi M, Amiri R. Analysing Petroleum Effluent Samples for Determination of Cadmium Using Carbon Nanotubes Followed by Atomic Absorption Spectrometry. Curr. Nanosci. 2018;14:545-554.

37. Wang J, Liu T-S, Huang Q-X, Ma Z-Y, Chi Y, Yan JH. Production and characterization of high quality activated carbon from oily sludge. Fuel Process. Technol. 2017;162:13-19.

38. Karamalidis AK, Voudrias EA. Leaching behavior of metals released from cement-stabilized/solidified refinery oily sludge by means of sequential toxicity characteristic leaching procedure. J. Environ. Eng. 2008;134:493-504.

39. Devi P, Saroha AK. Risk analysis of pyrolyzed biochar made from paper mill effluent treatment plant sludge for bioavailability and eco-toxicity of heavy metals. Bioresour. Technol. 2014;162:308-315.

40. Elektorowicz M, Muslat Z. Removal of heavy metals from oil sludge using ion exchange textiles. Environ. Technol. 2008;29: 393-399.

41. Wen J, Li Z, Luo N, et al. Binding characteristics of cadmium and zinc onto soil organic matter in different water managements and rhizosphere environments. Ecotoxicol. Environ. Saf. 2019;184:109633.

42. Chu Z, Fan X, Wang W, Huang W-C. Quantitative evaluation of heavy metals' pollution hazards and estimation of heavy metals' environmental costs in leachate during food waste composting. Waste Manage. 2019;84:119-128.

43. Wen C, Sheng H, Ren L, Dong Y, Dong J. Study on the removal of hexavalent chromium from contaminated groundwater using emulsified vegetable oil. Process Saf. Environ. Prot. 2017;109: 599-608.

44. Chaturvedi A, Bhattacharjee S, Mondal GC, Kumar V, Singh PK, Singh AK. Exploring new correlation between hazard index and heavy metal pollution index in groundwater. Ecol. Indic. 2019;97:239-246.

45. Zou Q, Xiang H, Jiang J, et al. Vanadium and chromium-contaminated soil remediation using VFAs derived from food waste as soil washing agents: A case study. J. Environ. Manage. 2019;232:895-901.

46. Wang X, Li C, Zhang B, Lin J, Chi Q, Wang Y. Migration and risk assessment of heavy metals in sewage sludge during hydrothermal treatment combined with pyrolysis. Bioresour. Technol. 2016;221:560-567.

47. Gong Z, Wang Z, Wang Z. Study on migration characteristics of heavy metals during oil sludge incineration. Pet. Sci. Technol. 2018;36:469-474.

48. Haroni NN, Badehian Z, Zarafshar M, Bazot S. The effect of oil sludge contamination on morphological and physiological 
characteristics of some tree species. Ecotoxicology 2019;28: 507-519.

49. Dastyar W, Raheem A, He J, Zhao M. Biofuel Production Using Thermochemical Conversion of Heavy Metal-Contaminated Biomass (HMCB) Harvested from Phytoextraction Process. Chem. Eng. J. 2019;358:759-785.

50. Song J, Shen Q, Wang L, et al. Effects of $\mathrm{Cd}, \mathrm{Cu}, \mathrm{Zn}$ and their combined action on microbial biomass and bacterial community structure. Environ. Pollut. 2018;243:510-518.

51. Tang J, Zhang J, Ren L, et al. Diagnosis of soil contamination using microbiological indices: A review on heavy metal pollution. J. Environ. Manage. 2019;242:121-130.

52. Shen GQ, Lu YT, Zhou QX, Hong JB. Interaction of polycyclic aromatic hydrocarbons and heavy metals on soil enzyme. Chemosphere 2005;61:1175-1182.

53. Zhang C, Nie S, Liang J, et al. Effects of heavy metals and soil physicochemical properties on wetland soil microbial biomass and bacterial community structure. Sci. Total Environ. 2016;557:785-790.

54. Wang Y, Dong B, Fan Y, et al. Nitrogen transformation during pyrolysis of oilfield sludge with high polymer content. Chemosphere 2019;219:383-389.

55. Tang X; Wei X; Chen S. Continuous Pyrolysis Technology for Oily Sludge Treatment in the Chain-Slap Conveyors. Sustainability 2019;11:1-10.

56. Lin B, Mallah MMA, Huang Q, Ali M, Chi Y. Effects of Temperature and Potassium Compounds on the Transformation Behavior of Sulfur during Pyrolysis of Oily Sludge. Energ. Fuel 2017;31:7004-7014.

57. Chiang HL, Lo JC, Tsai JH, Chang GM. Pyrolysis kinetics and residue characteristics of petrochemical industrial sludge. J. Air. Waste. Manage. 2000;50:272-277.

58. Napp AP, Pereira JES, Oliveira JS, et al. Comparative metagenomics reveals different hydrocarbon degradative abilities from enriched oil-drilling waste. Chemosphere 2018;209:7-16.

59. Farahani M, Mahmoudi D. Optimization, modeling and its conformity with the reality of physico-chemical and microbial processes of petroleum hydrocarbons reduction in soil: A case study of Tehran oil refinery. Environ. Earth Sci. 2018;77.

60. Micle V, Sur IM, Criste A, et al. Lab-scale experimental investigation concerning ex-situ bioremediation of petroleum hydrocarbons-contaminated soils. Soil. Sediment. Contam. 2018;27: 692-705.

61. Bezza FA, Chirwa EMN. Biosurfactant from Paenibacillus dendritiformis and its application in assisting polycyclic aromatic hydrocarbon $(\mathrm{PAH})$ and motor oil sludge removal from contaminated soil and sand media. Process Saf. Environ. Prot. 2015;98:354-364.

62. Daflon SDA, Guerra IL, Reynier MV, Cerqueira AC, Botta CR, Campos JC. Toxicity identification and evaluation (TIE) of a petroleum refinery wastewater. J. Environ. Sci. Health A Tox. Hazard. Subst. Environ. Eng. 2017;52:842-848.

63. Al-Hawash AB, Zhang X, Ma F. Removal and biodegradation of different petroleum hydrocarbons using the filamentous fungus Aspergillus sp. RFC-1. Microbiologyopen 2019;8:e00619.

64. Pugazhendi A, Wazin H, Qari H, Dhavamani J. Biodegradation of low and high molecular weight hydrocarbons in petroleum refinery wastewater by a thermophilic bacterial consortium. Environ. Technol. 2017;38:2381-2391.

65. Gao L-L, Lu Y-C, Zhang J-L, Li J, Zhang J-D. Biotreatment of restaurant wastewater with an oily high concentration by newly isolated bacteria from oily sludge. World J. Microbiol. Biotechnol. 2019;35.

66. Ghosh S, Chakraborty S. Influence of inoculum variation on formation and stability of aerobic granules in oily wastewater treatment. J. Environ. Manage. 2019;248:109239.

67. Li X-b, Liu J-t, Xiao Y-q, Xiao X. Modification technology for separation of oily sludge. J. Cent. South. Univ. T. 2011;18: 367-373.

68. Zhao M, Xang X, Liu D, et al. Insight into essential channel effect of pore structures and hydrogen bonds on the solvent extraction of oily sludge. J. Hazard. Mater. 2019;121826-121826.

69. Nezhdbahadori F, Abdoli MA, Baghdadi M, Ghazban F. A comparative study on the efficiency of polar and non-polar solvents in oil sludge recovery using solvent extraction. Environ. Monit. Assess. 2018;190.

70. Zhang J, Li J, Thring RW, Hu X, Song X. Oil recovery from refinery oily sludge via ultrasound and freeze/thaw. J. Hazard. Mater. 2012;203:195-203.

71. Samaksaman U, Kuo J-H, Peng T-H, Wey M-Y. Determination of Emission Characteristics during Thermal Treatment of Lube Oil and Heavy Metal Co-Contaminated Soil by Fluidized Bed Combustion. J. Environ. Eng. 2015;141:04015024.

72. Tian Y, Li J, Yan X, Whitcombe T, Thring R. Co-pyrolysis of metal contaminated oily waste for oil recovery and heavy metal immobilization. J. Hazard. Mater. 2019;373:1-10.

73. Deng S, Wang X, Tan H, et al. Thermogravimetric study on the Co-combustion characteristics of oily sludge with plant biomass. Thermochim. Acta. 2016;633:69-76.

74. Conesa JA. Molto J. Ariza J. Ariza M. Garcia-Barneto A. Study of the thermal decomposition of petrochemical sludge in a pilot plant reactor. J. Anal. Appl. Pyrolysis. 2014;107:101-106.

75. Lin B, Wang J, Huang Q, Chi Y. Effects of potassium hydroxide on the catalytic pyrolysis of oily sludge for high-quality oil product. Fuel 2017;200:124-133.

76. Tripathi M, Sahu JN, Ganesan P. Effect of process parameters on production of biochar from biomass waste through pyrolysis: A review. Renew. Sust. Energ. Rev. 2016;55:467-481.

77. Hu J, Danish M, Lou Z, et al. Effectiveness of wind turbine blades waste combined with the sewage sludge for enriched carbon preparation through the co-pyrolysis processes. J. Clean. Prod. 2018;174:780-787.

78. Chen XG, Jeyaseelan S. Study of sewage sludge pyrolysis mechanism and mathematical modeling. J. Environ. Eng-asce. 2001;127:585-593.

79. Zhou X, Jia H, Qu C, Fan D, Wang C. Low-temperature co-pyrolysis behaviours and kinetics of oily sludge: effect of agricultural biomass. Environ. Technol. 2017;38:361-369.

80. Shen Y, Chen X, Wang J, Ge X, Chen M. Oil sludge recycling by ash-catalyzed pyrolysis-reforming processes. Fuel 2016;182: 871-878.

81. Yang P, Wei J, Qu C. Vacuum pyrolysis of oil sludge from yanchang oilfield. Environ. Eng. 2015;33:101-103.

82. Chen L, Zhang X, Sun L, et al. Study on the Fast Pyrolysis 
of Oil Sludge and Its Product Distribution by PY-GC/MS. Energ. Fuels 2016;30:10222-10227.

83. Kan T, Strezov V, Evans T. Effect of the heating rate on the thermochemical behavior and biofuel properties of sewage sludge pyrolysis. Energ. Fuels 2016;30:1564-1570.

84. Ma Z, Gao N, Xie L, Li A. Study of the fast pyrolysis of oilfield sludge with solid heat carrier in a rotary kiln for pyrolytic oil production. J. Anal. Appl. Pyrolysis. 2014;105:183-190.

85. Shen L, Zhang DK. An experimental study of oil recovery from sewage sludge by low-temperature pyrolysis in a fluidised-bed. Fuel 2003;82:465-472.

86. Zhao S, Zhou X, Wang C, Jia H. Dewatering and low-temperature pyrolysis of oily sludge in the presence of various agricultural biomasses. Environ. Technol. 2018;39:2715-2723.

87. Jia H, Zhao S, Zhou X, et al. Low-temperature pyrolysis of oily sludge: roles of Fe/Al-pillared bentonites. Arch. Environ. Prot. 2017;43:82-90.

88. Hu Y, Yu W, Wibowo H, Xia Y, Lu Y, Yan M. Effect of catalysts on distribution of polycyclic-aromatic hydrocarbon (PAHs) in bio-oils from the pyrolysis of dewatered sewage sludge at high and low temperatures. Sci. Total Environ. 2019;667:263-270.

89. Gao N, Wang X, Quan C, Wu C. Study of oily sludge pyrolysis combined with fine particle removal using a ceramic membrane in a fixed-bed reactor. Chem. Eng. Process. 2018;128:276-281.

90. Cheng S, Chang F, Zhang F, Huang T, Yoshikawa K, Zhang $\mathrm{H}$. Progress in thermal analysis studies on the pyrolysis process of oil sludge. Thermochim. Acta. 2018;663:125-136.

91. Liu G, Song H, Wu J. Thermogravimetric study and kinetic analysis of dried industrial sludge pyrolysis. Waste Manage. 2015;41:128-133.

92. Yang Z, Kumar A, Apblett AW, Moneeb AM. Co-Pyrolysis of torrefied biomass and methane over molybdenum modified bimetallic HZSM-5 catalyst for hydrocarbons production. Green Chem. 2017;19:757-768.

93. Guillain M, Fairouz K, Mar SR, Monique F, Jacques L. Attrition-free pyrolysis to produce bio-oil and char. Bioresour. Technol. 2009;100:6069-6075.

94. Abnisa F, Wan Daud WMA. A review on co-pyrolysis of biomass: An optional technique to obtain a high-grade pyrolysis oil. Energ. Convers. Manage. 2014;87:71-85.

95. Parihar MF, Kamil M, Goyal HB, Gupta AK, Bhatnagar AK. An experimental study on pyrolysis of biomass. Process Saf. Environ. Prot. 2007;85:458-465.

96. Chiang W-F, Fang H-Y, Wu C-H, et al. Pyrolisis kinetics of rice husk in different oxygen concentrations. J. Environ. Eng. 2008;134:316-325.

97. Martínez JD, Puy N, Murillo R, Garcia T, Navarro MV, Mastral AM. Waste tyre pyrolysis - A review. Renew. Sust. Energ. Rev. 2013;23:179-213.

98. Kwon EE, Kim S, Lee J. Pyrolysis of waste feedstocks in CO2 for effective energy recovery and waste treatment. J. CO2. Util. 2019;31:173-180.

99. Siva M, Onenc S, Ucar S, Yanik J. Influence of oily wastes on the pyrolysis of scrap tire. Energ. Convers. Manage. 2013;75: 474-481.

100. Quek A, Vijayaraghavan K, Balasubramanian R. Methylene Blue Sorption onto Oxygenated Pyrolytic Tire Char: Equilibrium and Kinetic Studies. J. Environ. Eng. 2011;137:833-841.

101. Miandad R, Barakat MA, Aburiazaiza AS, Rehan M, Nizami AS. Catalytic pyrolysis of plastic waste: A review. Process Saf. Environ. Prot. 2016;102:822-838.

102. Shie J, Chang CY, Lin JP, Lee DJ, Wu CH. Use of inexpensive additives in pyrolysis of oil sludge. Energ. Fuels 2002;16: 102-108.

103. Shie JL, Lin JP, Chang CY, Lee DJ, Wu CH. Pyrolysis of oil sludge with additives of sodium and potassium compounds. Resour. Conserv. Recy. 2003;39:51-64.

104. Shie JL, Lin J-P, Chang C-Y, Shih S-M, Lee D-J, Wu C-H. Pyrolysis of oil sludge with additives of catalytic solid wastes. J. Anal. Appl. Pyrolysis. 2004;71:695-707.

105. Wang Z, Guo Q, Liu X, Cao C. Low temperature pyrolysis characteristics of oil sludge under various heating conditions. Energ. Fuel. 2007;21:957-962.

106. Wang Z, Gong Z, Wang Z, Fang P, Han D. A TG-MS study on the coupled pyrolysis and combustion of oil sludge. Thermochim. Acta. 2018;663:137-144.

107. Song Q, Zhao H, Jia J, et al. Characterization of the products obtained by pyrolysis of oil sludge with steel slag in a continuous pyrolysis-magnetic separation reactor. Fuel 2019;255: 115711.

108. Gong Z, Liu C, Wang M, Wang Z, Li X. Experimental study on catalytic pyrolysis of oil sludge under mild temperature. Sci. Total Environ. 2020;708:135039.

109. Liu C, Wang X, Ma P, et al. A new application of oily cold rolling mill sludge for preparing Fe2O3/graphene as anodes for lithium-ion batteries. Rsc. Adv. 2015;5:57383-57388.

110. Manara P, Zabaniotou A. Towards sewage sludge based biofuels via thermochemical conversion - A review. Renew. Sust. Energ. Rev. 2012;16:2566-2582.

111. Udayanga WDC, Veksha A, Giannis A, Lim T-T. Pyrolysis derived char from municipal and industrial sludge: Impact of organic decomposition and inorganic accumulation on the fuel characteristics of char. Waste Manage. 2019;83:131-141.

112. Zhou Y, Liu Y, Jiang W, Shao L, Zhang L, Feng L. Effects of pyrolysis temperature and addition proportions of corncob on the distribution of products and potential energy recovery during the preparation of sludge activated carbon. Chemosphere 2019;221:175-183.

113. Streit AFM, Côrtes LN, Druzian SP, et al. Development of high quality activated carbon from biological sludge and its application for dyes removal from aqueous solutions. Sci. Total Environ. 2019;660:277-287.

114. Meng F, Gong Z, Wang Z, Fang P, Li X. Study on a nitrogen-doped porous carbon from oil sludge for CO2 adsorption. Fuel 2019;251:562-571.

115. Li X, Wang Z, Guo L, Han D, Li B, Gong Z. Manganese oxide/hierarchical porous carbon nanocomposite from oily sludge for high-performance asymmetric supercapacitors. Electrochim. Acta. 2018;265:71-77.

116. Molto J, Barneto AG, Ariza J, Conesa JA. Gas production during the pyrolysis and gasification of biological and physico-chemical sludges from oil refinery. J. Anal. Appl. Pyrolysis. 2013;103:167-172.

117. Gong Z, Wang Z, Wang Z, et al. Study on pyrolysis of oil 
sludge with microalgae residue additive. Can. J. Chem. Eng. 2018;96:1919-1925.

118. Liu Y, Ran C, Siddiqui AR, et al. Pyrolysis of textile dyeing sludge in fluidized bed: Characterization and analysis of pyrolysis products. Energy 2018;165:720-730.

119. Yu G, Chen D, Arena U, Huang Z, Dai X. Reforming sewage sludge pyrolysis volatile with Fe-embedded char: Minimization of liquid product yield. Waste Manage. 2018;73:464-475.

120. Graham EJS, Dean CA, Yoshida TM, et al. Oil and gas produced water as a growth medium for microalgae cultivation: A review and feasibility analysis. Algal Res. 2017;24:492-504.

121. Majee U, Chattopadhyay GN, Chaudhury S. Optimization of the quality of reverse osmosis-treated coal bed water in relation to its effect on soil health. Environ. Earth Sci. 2017;76:1-8.

122. Milato JV, Franca RJ, Marques MRC. Pyrolysis of oil sludge from the offshore petroleum industry: influence of different mesoporous zeolites catalysts to obtain paraffinic products. Environ. Technol. 2019;1650833:1-10.

123. Johnson OA, Affam AC. Petroleum sludge treatment and disposal: A review. Environ. Eng. Res. 2019;24:191-201.

124. Ziglio MF, Azevedo EM, Dweck J. Study of treatments to remove water from petroleum sludge and evaluation of kinetic parameters by thermal analysis using isoconversional methods. J. Therm. Anal. Calorim. 2019;138:3603-3618.

125. Al-Doury MMI. Treatment of oily sludge using solvent extraction. Pet. Sci. Technol. 2019;37:190-196.

126. Ille Y, Sanchez FA, Dahmen N, Pereda S. Multiphase Equilibria Modeling of Fast Pyrolysis Bio-Oils. Group Contribution Associating Equation of State Extension to Lignin Monomers and Derivatives. Ind. Eng. Chem. Res. 2019;58:7318-7331.

127. Chen X, Che Q, Li S, et al. Recent developments in lignocellulosic biomass catalytic fast pyrolysis: Strategies for the optimization of bio-oil quality and yield. Fuel Process. Technol. 2019;196.

128. Liang J, Xu X, Yu Z, Chen L, Liao Y, Ma X. Effects of microwave pretreatment on catalytic fast pyrolysis of pine sawdust. Bioresour. Technol. 2019;293:122080.

129. Mohammadi S, Mirghaffari N. A preliminary study of the preparation of porous carbon from oil sludge for water treatment by simple pyrolysis or $\mathrm{KOH}$ activation. New Carbon Mater. 2015;30:310-318.

130. Vamvuka D, Sfakiotakis S, Pantelaki O. Evaluation of gaseous and solid products from the pyrolysis of waste biomass blends for energetic and environmental applications. Fuel 2019;236: 574-582.

131. Pielsticker S, Schloegel K, Kreitzberg T, Hatzfeld O, Kneer R. Biomass pyrolysis kinetics in a fluidized bed reactor: Measurements and plausibility verification for reaction conditions. Fuel 2019;254:115589.

132. Dhanalakshmi CS, Madhu P. Biofuel production of neem wood bark (Azadirachta indica) through flash pyrolysis in a fluidized bed reactor and its chromatographic characterization. Energ. Source. Part A. 2019.

133. Klinger J, Westover TL, Emerson RM, et al. Effect of biomass type, heating rate, and sample size on microwave enhanced fast pyrolysis product yields and qualities. Appl. Energ. 2018;
228:535-545.

134. Mao X, Kang Q, Liu Y, et al. Microwave-assisted pyrolysis of furfural residue in a continuously operated auger reactor: Biochar characterization and analysis. Energy 2019;168: 573-584.

135. Gomez V, Wright K, Esquenazi GL, Barron AR. Microwave treatment of a hot mill sludge from the steel industry: en route to recycling an industrial waste. J. Clean. Prod. 2019;207:182-189.

136. Hossain MA, Ganesan P, Jewaratnam J, Chinna K. Optimization of process parameters for microwave pyrolysis of oil palm fiber (OPF) for hydrogen and biochar production. Energ. Convers. Manage. 2017;133:349-362.

137. Chen Y-R. Microwave pyrolysis of oily sludge with activated carbon. Environ. Technol. 2016;37:3139-3145.

138. Liew RK, Nam WL, Chong MY, et al. Oil palm waste: An abundant and promising feedstock for microwave pyrolysis conversion into good quality biochar with potential multi-applications. Process Saf. Environ. Prot. 2018;115:57-69.

139. Kouhi M, Shams K. Bulk features of catalytic co-pyrolysis of sugarcane bagasse and a hydrogen-rich waste: The case of waste heavy paraffin. Renew. Energ. 2019;140:970-982.

140. Abdelhadi SO, Dosoretz CG, Rytwo G, Gerchman Y, Azaizeh H. Production of biochar from olive mill solid waste for heavy metal removal. Bioresour. Technol. 2017;244:759-767.

141. Jin Z, Chang F, Meng F, et al. Sustainable pyrolytic sludge-char preparation on improvement of closed-loop sewage sludge treatment: Characterization and combined in-situ application. Chemosphere 2017;184:1043-1053.

142. Thangalazhy-Gopakumar S, Al-Nadheri WMA, Jegarajan D, Sahu JN, Mubarak NM, Nizamuddin S. Utilization of palm oil sludge through pyrolysis for bio-oil and bio-char production. Bioresour. Technol. 2015;178:65-69.

143. Reckamp JM, Garrido RA, Satrio JA. Selective pyrolysis of paper mill sludge by using pretreatment processes to enhance the quality of bio-oil and biochar products. Biomass Bioenerg. 2014;71:235-244.

144. Leng L, Li J, Yuan X, et al. Beneficial synergistic effect on bio-oil production from co-liquefaction of sewage sludge and lignocellulosic biomass. Bioresour. Technol. 2018;251:49-56.

145. Huang F, Yu Y, Huang H. Temperature influence and distribution of bio-oil from pyrolysis of granular sewage sludge. J. Anal. Appl. Pyrolysis. 2018;130:36-42.

146. Park HJ, Dong J-I, Jeon J-K, et al. Effects of the operating parameters on the production of bio-oil in the fast pyrolysis of Japanese larch. Chem. Eng. J. 2008;143:124-132.

147. Chalov KV, Lugovoy YV, Doluda VY, et al. Influence of metals chlorides on oil-slime thermocatalytic processing. Chem. Eng. J. 2014;238:219-226.

148. Pawlak-Kruczek H, Krochmalny K, Wnukowski M, Niedzwiecki L. Slow Pyrolysis of the Sewage Sludge With Additives: Calcium Oxide and Lignite. J. Energ. Resour-Asme. 2018;140:1-9.

149. Yu Y, Yu J, Sun B, Yan Z. Influence of catalyst types on the microwave-induced pyrolysis of sewage sludge. J. Anal. Appl. Pyrolysis. 2014;106:86-91.

150. Zhang Q, Kano J. A new approach for hydrogen generation 
from sewage sludge. Bioresour. Technol. 2016;201:191-194.

151. Sun Y, Chen J, Zhang Z. General roles of sludge ash, $\mathrm{CaO}$ and $\mathrm{Al} 2 \mathrm{O} 3$ on the sludge pyrolysis toward clean utilizations. Appl. Energ. 2019;233:412-423.

152. Cheng S, Wang Y, Gao N, Takahashi F, Li A, Yoshikawa K. Pyrolysis of oil sludge with oil sludge ash additive employing a stirred tank reactor. J. Anal. Appl. Pyrolysis. 2016;120: 511-520.

153. Cheng S, Takahashi F, Gao N, Yoshikawa K, Li A. Evaluation of Oil Sludge Ash as a Solid Heat Carrier in the Pyrolysis Process of Oil Sludge for Oil Production. Energ. Fuels 2016;30:5970-5979 